Establishment mode choice by Chinese firms in Latin America: The role of host country-specific experience and government official visits

\title{
Diego Quer*
}

Department of Management, University of Alicante, Spain

P.O. Box 99, E-03080 Alicante, Spain

Tel and Fax: (+34) 965903606

e-mail: diego.quer@ua.es

(iD) http://orcid.org/0000-0002-5814-6411

\section{Laura Rienda}

Department of Management, University of Alicante, Spain

P.O. Box 99, E-03080 Alicante, Spain

Tel and Fax: (+34) 965903606

e-mail: laura.rienda@ua.es

\section{Rosario Andreu}

Department of Management, University of Alicante, Spain

P.O. Box 99, E-03080 Alicante, Spain

Tel and Fax: (+34) 965903606

e-mail: rosario.andreu@ua.es 


\section{Brief biosketch of authors}

\section{Diego Quer}

$\mathrm{He}$ is an associate professor at the Department of Management, University of Alicante, Spain. His research interests include several topics of international management, such as entry modes and emerging-market multinationals, with a special focus on the Chinese context. He has published in Asia Pacific Journal of Management, International Business Review, Family Business Review, Asian Business \& Management, Management Decision, Journal of the Asia Pacific Economy, European Journal of International Management, Cross Cultural \& Strategic Management, Chinese Management Studies, China: An International Journal, and International Journal of Hospitality Management, among others.

\section{Laura Rienda}

She is an associate professor at the Department of Management, University of Alicante, Spain. Her primary research interests cover family business management, international management, and business and management in India. Her research has been published in journals like Family Business Review, Asia Pacific Journal of Management, Journal of the Asia Pacific Economy, Asian Business \& Management, Management Decision, European Journal of International Management, Cross Cultural \& Strategic Management, Chinese Management Studies, Journal of General Management, Journal of Indian Business Research, and Journal of Asia Business Studies.

\section{Rosario Andreu}

She is an associate professor at the Department of Management, University of Alicante, Spain. Her primary research interests focus on tourism management, specializing in diversification strategies and China's tourism. Her research has appeared in journals such as International 
Business Review, Tourism Economics, International Journal of Hospitality Management, International Journal of Contemporary Hospitality Management, International Journal of Tourism Research, Asian Business \& Management. Management Decision, Cross Cultural \& Strategic Management, European Journal of International Management, UCJC Business and Society Review, Journal of China Tourism Research, and Cuadernos de Turismo.

\section{Executive summary}

This study addresses establishment mode decisions by emerging-market multinational enterprises entering other emerging economies. More precisely, we examine the influence of prior host country experience and home government official visits on the choice between the acquisition of a local company and the creation of a new subsidiary from scratch. By analyzing 315 investments carried out by Chinese firms in Latin America, we obtain that they are more likely to enter through an acquisition when they have established prior subsidiaries in the host country. Moreover, recent Chinese government official visits contribute to mitigate the difficulties of an acquisition for those companies with less local experience.

Keywords: Chinese firms, Latin America, establishment mode, local experience, government visits.

\section{INTRODUCTION}

Establishment mode choice is a key decision for multinational enterprises (MNEs) when entering a foreign country. It refers to the choice between an acquisition, namely, the takeover of an already existing company in the host country, and a greenfield subsidiary, i.e., the creation of a new subsidiary from scratch. This decision has important implications for both the foreign firm and the host country. As for the foreign firm, the acquisition of a local company may provide useful resources that facilitate the entry in an unknown environment. 
Despite of this, uncertainty may hinder the identification and assessment of potential local targets and generate additional difficulties when integrating the acquired unit. Regarding the host country, an acquisition may raise legitimacy concerns, since it represents the transfer of existing facilities to the new acquirer, thus generating less job creation opportunities than a greenfield subsidiary. Moreover, the negative reaction to a foreign acquisition may be reinforced if the local target belongs to an industry considered strategic by the host government.

Prior research has identified a number of firm-, industry-, and country-specific factors as determinants of establishment mode choice abroad (Slangen \& Hennart, 2007). However, as highlighted by some recent literature reviews, there are still significant research gaps (Dikova \& Brouthers, 2016; Klier et al., 2017). First, most past studies mainly focused on direct relationships, not addressing the potential effects of interactions between determinants, in particular, the role played by contextual factors as moderators of the influence of firmspecific resources. Second, in spite of the growing relevance of emerging-market MNEs, empirical studies analyzing their establishment mode choice are still scant. Third, we know far less about this choice when emerging-market MNEs enter other emerging economies.

Outward foreign direct investment (OFDI) flows from an emerging economy to other emerging economies represent a peculiar context that may challenge the conventional wisdom (Wright et al., 2005). The competitive disadvantage of operating in an underdeveloped institutional environment at home may turn into a competitive advantage when emergingmarket MNEs do business in a host country with similar weak institutional conditions (Cuervo-Cazurra \& Genc, 2008). In addition, past research suggests that home government support for going global also matters, allowing emerging-market MNEs to offset their latecomer disadvantages (Luo, Xue, \& Han, 2010). This may become a key factor for those emerging-market MNEs with low host market-specific experience. Support policies from the 
home government may provide them with useful resources to take more risks when choosing the establishment mode. Hence, analyzing this decision in the context of emerging economies as home and host countries deserves research attention, since it may allow obtaining new insights on the applicability of extant theoretical underpinnings for explaining the less conventional behavior of emerging-market MNEs (Cuervo-Cazurra, 2012).

Among emerging-market MNEs, those from China stand out, as their international activity has grown exponentially in the last decade. OFDI flows by Chinese companies have multiplied by six between 2007 and 2017, to the point that China is already the third largest investor in the world, only surpassed by the United States and Japan (UNCTAD, 2018). Emerging markets are increasingly attracting Chinese investments, with Latin American countries becoming key targets. Latin America is already the second main destination of China's OFDI, only behind Asia (NBS, 2018). The Chinese government is playing a significant role in boosting political and economic ties with Latin America, by signing investment and trade agreements (Fornes \& Butt-Philip, 2011). Moreover, by reinforcing bilateral diplomatic relationships with Latin American countries, including official visits, the Chinese government facilitates the access of Chinese MNEs to local natural resources, also reducing potential conflicts with host governments in a region where political risk is higher for MNEs from other home countries (Shapiro, Vecino, \& Li, 2018).

Therefore, the aim of our study is to deepen our knowledge of how Chinese MNEs make decisions on establishment mode in other emerging economies such as those of Latin America. More precisely, drawing on information economics and institutional theory, we seek to answer the following questions. First, does prior host country experience lead Chinese MNEs to prefer the acquisition of a local firm rather than a greenfield investment? Second, can Chinese government official visits to the focal host country mitigate the lack of firm's prior experience on that local environment? 
We offer a number of contributions to the literature on emerging-market MNEs and establishment mode decisions. First, we contribute to information economics and institutional theory by addressing how good bilateral diplomatic activities may be an institutional tool that allows alleviating information asymmetries and enhancing local legitimacy in the host environment. By doing so, we contribute to the current epistemological debate on the validity of traditional theoretical frameworks in the case of emerging-market MNEs. Second, we provide new empirical evidence to establishment mode decisions by emerging-market MNEs when they enter other emerging economies, a research topic that has received scant attention so far. Third, we offer insights on how diplomacy may help foreign firms lacking local knowledge to establish through acquisitions.

In the remainder of this article, we first provide the theoretical background for developing hypotheses on the relationship between host country-specific experience and establishment mode choice, as well as the moderating influence of official government visits. In the subsequent section, we explain the methodology of our empirical analysis. After presenting the results, we conclude with a discussion and a suggestion for potential future research on this topic.

\section{THEORY AND HYPOTHESES DEVELOPMENT}

Extant literature emphasizes that firm-specific characteristics may affect OFDI decisions, in particular, those related to establishment mode choice (Nagano, 2013). One of these characteristics is firm's previous experience with the host country (Drogendijk \& Slangen, 2006). Foreign firms may obtain knowledge about the host country through experiential learning (Pedersen \& Shaver, 2011). Learning to operate effectively in the host market is largely a by-product of doing business there and it is irreplaceable by knowledge accumulated in other countries (Larimo, 2003; Liu et al., 2016). Firms that are familiar with a foreign 
market have a better understanding of the peculiarities of the local context and they may have developed routines to deal with the challenges of operating in that market (Padmanabhan \& Cho, 1999; Slangen \& Hennart, 2008). This type of location-bound learning helps firms to reduce liabilities of foreignness and to develop knowledge on the institutional aspects of operating an entry mode in a specific destination (Schwens et al., 2018). As a result, prior literature posits that experience-based resources have an impact on establishment mode choice in foreign markets (Klier et al., 2017).

Information economics provides a theoretical explanation for this relationship. Information economics analyzes how information affects economic decisions by focusing on the existence of information asymmetries between the parties involved in a transaction, i.e. when one party has more or better information than the other (Akerlof, 1970; Stigler, 1961). These information asymmetries are usually present in cross-border acquisitions, since they have two inherent problems, namely, the inspection and the interaction problems (Ravenscraft $\&$ Scherer, 1987). Inspection problems derive from the fact that the seller has typically better information than the buyer so the latter have more difficulties to evaluate the target firm exante. Interaction problems refer to the ex-post integration of the acquired firm into the acquirer's corporation. Acquisitions are more difficult to manage than greenfield subsidiaries, especially because both the acquiring and the acquired companies have their own corporate cultures and post-integration obstacles may arise (Hennart \& Park, 1993).

Information asymmetries are likely to be more important for those firms with low host-country specific experience, since they will be less familiar with existing local firms and they will face more difficulties to evaluate and integrate target firms, thus preferring to establish a subsidiary from scratch (Mudambi \& Mudambi, 2002; Slangen \& Hennart, 2007). Conversely, firms with prior experience in the host country will have a better understanding of how local firms operate and are organized and they will know more about local culture and 
communication style (Slangen \& Hennart, 2008). Hence, host country experience is a kind of valuable knowledge that allows foreign firms to identify and evaluate local firms that are potential acquisition targets and to negotiate better with local managers in order to reduce acquisition premiums, helping them to solve the above-mentioned ex-ante inspection problems (Dikova, Sahib, \& van Witteloostuijn, 2010; Larimo, 2003). Moreover, local experience allows the firm to learn the peculiarities of local culture, which can reduce implementation obstacles and facilitate knowledge transfer to the acquired unit, overcoming ex-post interaction problems (Barkema \& Vermeulen, 1998). Therefore, host country-specific experience is a valuable resource that firms are more likely to exploit through acquisitions (Klier et al., 2017).

In addition, local experience may also contribute to the legitimacy of the foreign firm in the host country, namely, the degree to which it is perceived as acceptable by stakeholders, including the host government (Kostova \& Zaheer, 1999). As the firm accumulates host country experience, it will be better known among host government branches, even it might have established ties with them (Slangen, 2013). By becoming embedded in these local networks, the status of the foreign firm may change from that of an 'outsider' to more of an 'insider' (Cantwell \& Mudambi, 2011). As a consequence, the local environment becomes more accustomed to the presence of that firm and tends to perceive it as more legitimate (Zaheer \& Mosakowski, 1997). These legitimacy issues lead us to consider also insights from the institutional theory.

Institutional theory deals with the political, social and economic systems that surround firms and shape their behavior (North, 1990). It is one of the most usual theoretical underpinnings used for analyzing strategies in emerging economies (Xu \& Meyer, 2013). Institutional variables have a strong impact on emerging-market MNEs' decision-making process (Cui \& Jiang, 2010; Peng, Wang, \& Jiang, 2008). The 'rules of the game' in emerging 
economies are less established than in developed ones and are usually more local context specific (Buckley et al., 2016). For these reasons, the institutional theory is considered a good way to lay a foundation for the international behavior of emerging-market MNEs, in particular, when they enter other emerging economies (Wright et al., 2005).

Drawing on this perspective, some scholars argue that foreign investors need to accommodate to the institutional pressures they are exposed in host countries to build local legitimacy (Kostova, Roth, \& Dacin, 2008; Xu \& Shenkar, 2002). Apart from firm's host country experience, bilateral diplomatic relations between the home and the host country may also play a role in facilitating local legitimacy building. Diplomatic relations between governments symbolize an interaction between home and host institutions and they may act as a 'bridge' between countries, thus facilitating investment decisions (Duanmu, 2014; Li et al., 2018; Shapiro et al., 2018). Friendly diplomatic relations may stabilize host country institutional environment, reducing the risk perceived by foreign firms and enhancing their legitimacy in the host country (Child \& Marinova, 2014; Li et al., 2018).

Establishment mode choice has implications in terms of local legitimacy for the investing company. A greenfield investment may provide greater contributions to local development, since it represents the establishment of a new firm from scratch. Thus, it generates more potential opportunities for new job creation than an acquisition, where local facilities and existing jobs are transferred to a foreign acquirer. In addition, acquisitions may also raise suspicions in some host countries and generate institutional resistance, especially when the local target involves assets that are considered essential for the local economy, such as technology, natural resources, or utilities (Cuervo-Cazurra et al., 2014; Meyer et al., 2014; Quer, Rienda, \& Andreu, 2019a). Consequently, greenfield investments may be preferred by the host government. However, good diplomatic relations may contribute to reduce the legitimacy concerns of acquisitions, not only by the endorsement of the focal investment by 
the home government, but also by facilitating reciprocal business opportunities for local firms in the investor's home country. Government official visits are a key tool for building these bilateral diplomatic relationships between countries. They are the highest form of diplomacy and they usually pave the way for further development of bilateral relations (Nitsch, 2007). Therefore, government official visits may facilitate acquisitions of local companies.

In light of the above, drawing on information economics and institutional theory, next we propose several hypotheses regarding the influence of both host country-specific experience and government official visits on establishment mode choice by Chinese MNEs in Latin America.

\section{Host country-specific experience and establishment mode choice}

As pointed out before, information economics suggests that foreign firms would prefer greenfield investments instead of acquisitions when lacking the require knowledge to evaluate and integrate local targets (Slangen \& Hennart, 2007). Most extant empirical studies support this relationship, showing that prior host country experience tend to increase the likelihood of choosing acquisitions instead of greenfield investments (Andersson \& Svensson, 1994; Barkema \& Vermeulen, 1998; Boellis et al., 2016; Demirbag, Tatoglu, \& Glaister, 2008; Drogendijk \& Slangen, 2006; Shaver, 1998; Slangen, 2013; Slangen \& Hennart, 2008). However, empirical evidence is not conclusive since quite a few studies report insignificant results (Bhaumik \& Gelb, 2005; Cho \& Padmanabhan, 1995; Dow \& Larimo; 2011; Hennart \& Park, 1993; Larimo, 2003; Padmanabhan \& Cho, 1999; Quer et al., 2019a; Slangen, 2011) and a few others find a negative relationship between host country experience and acquisitions (Chang \& Rosenzweig, 2001; Chen, 2008; Rienda, Claver, \& Quer, 2013). Actually, it has been also argued that lack of market knowledge may lead the firm to acquire a local firm in order to get access to that tacit knowledge (Dikova \& Brouthers, 2016). 
Anyway, the vast majority of prior research addressing the influence of host countryspecific experience on establishment mode choice focused on developed-country MNEs. Only a few studies looked at emerging markets as home countries (Quer et al., 2019a; Rienda et al., 2013) or as host countries (Bhaumik \& Gelb, 2005; Demirbag et al., 2008), and none of them focused simultaneously on emerging markets as home and host countries.

Emerging-market MNEs operate in a home country with a less developed institutional environment. As stated above, although this may be considered a competitive disadvantage, it may become an advantage when doing business in other emerging economies with similar weak institutions (Cuervo-Cazurra \& Genc, 2008). Therefore, more than knowledge on how to do business in an emerging market, lack of information about potential local targets may be more important when emerging-market MNEs enter other emerging economies. Furthermore, in the case of Chinese MNEs in Latin America, the relative high cultural distance between home and host countries may increase post-acquisition difficulties. In other words, the socalled inspection and interaction problems may be more relevant than knowledge on how to do business in an emerging market.

Drawing on the preceding reasoning from information economics, we argue that prior experience about the focal Latin American country makes the Chinese firm more knowledgeable and confident about local targets helping it to overcome inspection and interaction problems. Thus, host country knowledge is a kind of specific international experience that may be considered a 'distance-bridging' factor (Child, $\mathrm{Ng}, \&$ Wong, 2002) that increases the likelihood of subsequent establishments through acquisitions (Dow \& Larimo, 2011). As a result, we propose:

Hypothesis 1: The greater the host country-specific experience by Chinese MNEs, the greater their propensity to establish through acquisitions rather than through greenfield investments. 


\section{Government official visits and establishment mode choice}

As pointed out before, although most prior studies report that host country experience is positively associated with acquisitions, there are also studies reporting a not significant or even a negative relationship. Therefore, we could ask why firms with little host country experience may undertake acquisitions. The answer may arise from the above-mentioned good bilateral diplomatic relationships between the home and the host country that may be a substitute of host country experience as a 'distance-bridging' factor. The support provided by the home government may offset the need to accumulate prior host country-specific experience ( $\mathrm{Lu}$ et al., 2014). This leads us to consider the role played by institutions in shaping the behavior of Chinese MNEs, especially when choosing the establishment mode in other emerging economies.

Child and Marinova (2014) argue that the Chinese government can stabilize host country institutional environments for Chinese firms through the development of strong bilateral diplomatic relations. In particular, prior research reports that, by organizing government official visits to a host country, the Chinese government can be viewed as a 'signaler' who may alleviate information asymmetries for Chinese investors in the host environment (Voss et al., 2017). Furthermore, diplomacy may catalyze networking between Chinese firms and potential local targets and increase legitimacy in the host country (Li et al., 2018). Thus, Chinese government visits contribute to create a friendlier local environment for Chinese investors that allow them to overcome the liability of foreignness (Zhang, Jiang, \& Zhou, 2014). This may also help to alleviate the inspection and interaction problems involved in the acquisition of a local firm.

These positive effects of Chinese government official visits may be even more evident in other emerging economies such as those of Latin America (Quer et al., 2019b). During high-profile state visits by China's leaders to developing countries, China has signed wide- 
ranging bilateral economic cooperation agreements along with the granting of China's development aids generally allocated to infrastructure projects in the focal host country (Buckley et al., 2018). For that reason, we argue that the legitimacy concerns by the host government derived from the acquisition of a local target can be alleviated in emerging economies by means of such diplomatic activities. Overall, the latter may be considered as a facilitator of acquisitions for those investing firms lacking host country experience. Based on the foregoing reasoning, we propose:

Hypothesis 2: Recent Chinese government official visits to the focal host country moderate the impact of prior entry experience on the choice of acquisitions by Chinese MNEs.

\section{DATA AND METHOD}

\section{Sample}

Our data were mainly obtained from the Monitor of Chinese OFDI in Latin America and the Caribbean, developed by the Academic Network of Latin America and the Caribbean on China (Red ALC-China). This database covers Chinese investments in the region dating back to 2000 and includes information on the establishment mode used by each company. In order to improve data reliability, we resorted to other secondary data sources: the China Global Investment Tracker (a comprehensive database of China's OFDI since 2005, compiled by the American Enterprise Institute and the Heritage Foundation), news items reported by Chinese media (such as Xinhua, China Daily, and Global Times) and information provided by each firm's corporate website.

Our final sample contains 315 OFDIs carried out by Chinese firms in 15 Latin America countries between 2000 and 2017. Table 1 reports a more detailed description of our sample. Greenfield investments $(209,66.3 \%)$ prevail over acquisitions $(106,33.7 \%)$ as 
establishment modes. Brazil leads the ranking of top destinations (134 investments), followed by Mexico (49), Peru (29), and Argentina (25), these four countries accounting for over 75 percent of the observations. By industry, companies belonging to materials industry predominate (53 investments), followed by telecommunications services (52), energy (50), industrials (45), and consumer discretionary (44). These five industries account for 77 percent of the OFDIs included in our sample. As for individual companies, Huawei (15 investments), China National Petroleum Corporation [CNPC] (12), China Three Gorges (8), Sinopec (7), State Grid (7), and Aluminum Corporation of China [Chinalco] (6) are the top investors.

'Insert Table 1 here'

\section{Dependent variable}

Establishment mode. This is a dummy variable that equals to one if the Chinese MNE acquired a local company, and zero if it established a greenfield subsidiary (Chen et al., 2017; Hennart \& Park, 1993; Larimo, 2003; Meyer et al., 2014; Quer et al., 2019a; Rienda et al., 2013). Following prior studies on establishment mode choice, joint ventures have been included in the greenfield investment category (Barkema \& Vermeulen, 1998; Brouthers \& Hennart, 2007).

\section{Explanatory variable}

Host country experience. We measured prior local experience through a dummy variable coded one if the Chinese firm already had subsidiaries in the host country before it established the focal subsidiary, and zero otherwise (Estrin, Baghdasaryan, \& Meyer, 2009; Li et al., 2018; Nagano, 2013; Quer et al., 2019a, 2019b; Slangen, 2011).

\section{Moderating variable}

Government visit. We created a dummy variable equal to one if a Chinese government delegation paid an official visit to the host country in the focal year or in the immediate previous year, and zero otherwise (Quer et al., 2019b; Voss et al., 2017). Collecting data from 
the Ministry of Foreign Affairs of the People's Republic of China website, we included visits by the Chinese President, Prime Minister, Ministers or Vice Ministers of Commerce, Foreign Affairs, Transport, etc., as well as senior officials of other Chinese governmental institutions such as the National People's Congress, the Politburo Standing Committee, and the Chinese People's Political Consultative Conference.

\section{Control variables}

We also included a number of control variables that, according to extant research, might also influence establishment mode choice. Most prior studies report a negative relationship between cultural distance and acquisitions (Dikova \& Brouthers, 2016). The underlying arguments are related to the higher costs of managing acquisitions in culturally-distant countries (Kogut \& Singh, 1988) and the difficulties to transfer management practices to acquired units in such destinations (Drogendijk \& Slangen, 2006). However, other studies suggest that acquisitions allow to access local knowledge thus reducing uncertainties when cultural distance is high (Brouthers \& Brouthers, 2000; Rienda et al., 2013). Hence, we controlled for the cultural distance between China and each host Latin American country using the Kogut and Singh's (1988) index, that has been extensively used in prior research (Estrin et al., 2009; Larimo, 2003; Quer et al., 2019a; Rienda et al., 2013; Slangen, 2011; Slangen \& Hennart, 2008). We based on the extended Hofstede's model with six dimensions (Hofstede, Hofstede, \& Minkov, 2010).

It has been argued that the diaspora living in the host country is a kind of social capital that may facilitate acquisition of local market information by foreign firms from the diaspora's country of origin (Amighini, Rabellotti, \& Sanfilipo, 2012; Anwar \& Mughal, 2013; Li, Li, \& Shapiro, 2012). As a result, it may contribute to reduce the perceived uncertainty in the host country, thus affecting the choice between acquisitions and greenfield investments. Therefore, we controlled for the potential effect of the Chinese diaspora, using 
the percentage of ethnic Chinese to the total population in each Latin American country. In doing so, we used data from the Shao Center of the Ohio University and the CIA World Factbook.

The effectiveness of the host government is considered a facilitator to secure acquisitions and legally protect long-term interests of emerging-market MNEs when they enter other emerging economies (Deng \& Yang, 2015). We controlled for this factor using government effectiveness, one of the six dimensions of the Worldwide Governance Indicators proposed by the World Bank for measuring the governance infrastructure quality of a country (Kaufmann, Kraay, \& Mastruzzi, 2009). This variable deals with the quality of public services, civil service and policies, the independence from political pressures, and the credibility of government's commitment to these policies.

OFDI drivers may also affect establishment mode choice. First, past studies suggest that natural resource-seeking acquisitions by Chinese firms may raise suspicions in some host countries, in particular, when the targets are critical resources for the local economy (Globerman \& Shapiro, 2009). Hence, we controlled for resource endowment using the percentage of fuel, ore, and metal exports to total merchandize exports by each host country, with a log transformation (Buckley et al., 2016; Zhang et al., 2014). Second, compared to greenfield investments, acquisitions allow a quicker entry (Globerman \& Shapiro, 2009). For that reason, acquisitions have been the usual establishment mode by Chinese MNEs to access the strategic assets they need to catch up with incumbent competitors (Luo \& Tung, 2007). We controlled for this factor using technology endowment, measured through the log of the total number of patent applications in the host country divided by its GDP (Buckley et al., 2016; Meyer et al., 2014). Third, past studies argue that acquisitions will be preferred in slowgrowth markets as they do not increase production capacity, reducing the risk of retaliation (Brouthers \& Brouthers, 2000). Actually, by acquiring a competitor, the foreign firm may 
reduce competition, whereas a greenfield investment creates a new competitor (Hennart and Park, 1993). Conversely, high-growth markets can support production capacity growth (Larimo, 2003) and entail a lower threat of curbing incumbents' earnings (Dikova \& van Witteloostuijn, 2007). Thus, we included market growth as a control variable, measured by the annual percentage of GDP growth in each host country (Boellis et al., 2016; Buckley et al., 2016; Zhang et al., 2014). For these three drivers, we collected data from the World Development Indicators (WDI) of the World Bank with one-year lag.

In addition, a lower level of development in the host country increases information asymmetries for foreign firms (Meyer et al., 2009) whereas a higher development level may increase the availability of attractive acquisition candidates that fulfill the requirements of the investing firm (Larimo, 2003). Therefore, we controlled for the level of economic development, using a dummy variable, coded one if the host country is a member of the Organization for Economic Co-operation and Development (OECD), and zero otherwise (Buckley et al., 2007; Gubbi et al., 2010).

Past research considered the size of the investing firm as a proxy for its availability of resources. However, empirical evidence is mixed, since some studies reported a positive relationship between firm size and acquisitions, while others found just the opposite or even no relationship (Dikova \& Brouthers, 2016). Thus, we controlled for firm size using the log of the number of employees (Boellis et al., 2016; Demirbag et al., 2008; Xu et al., 2018).

OFDI by Chinese state-owned enterprises (SOEs) may raise institutional resistance in host countries because of the conflicting roles of the private sector and the government in the economy (Lattemann et al., 2017). As a result, several studies show that Chinese SOEs adapt their establishment modes to overcome distrust and gain local legitimacy in host countries (Meyer et al., 2014; Quer et al., 2019a). Moreover, Xie, Reddy, and Liang (2017) argue that Chinese SOEs are more likely to invest in host countries with strong political connections and 
high export dependence on China, as is the case of some Latin American countries. For that reason, we included state ownership as a control, through the percentage of state equity in the Chinese investor (Duanmu, 2014; Quer et al., 2019a).

It has been also argued that those firms with extensive experience with a particular establishment mode tend to use the same mode in subsequent entries. This is either because they have accumulated the skills needed to manage that establishment mode, reducing implementation costs, or because they copy their past behavior to reduce risk (Chang \& Rosenzweig, 2001; Padmanabhan \& Cho, 1999). Hence, we controlled for establishment mode experience, distinguishing between acquisition experience and greenfield experience (Dikova \& van Witteloostuijn, 2007; Drogendijk \& Slangen, 2006; Slangen, 2011, 2013; Slangen \& Hennart, 2008). Both variables were measured as the log of one plus the number of prior acquisitions or greenfield investments carried out worldwide by the Chinese firm before the current establishment mode decision.

Another type of experience that may also affect establishment mode decisions is the so-called vicarious experience, i.e., the experience of others that share a common characteristic (Jiang, Holburn, \& Beamish, 2014). Firms tend to follow similar organizations that have been successful in a new market (Haveman, 1993). One of those common features is a similar cultural background derived from the country of origin. Companies from the same home country usually face the same obstacles in a host country and absorbing their experience may be easier (Cohen \& Levinthal, 1990; Tan \& Meyer, 2011). Thus, following past studies on Chinese MNEs, we controlled for vicarious experience by considering prior investments by other Chinese firms in the host country (Lu et al., 2014; Yuan \& Pangarkar, 2010). We used a dummy variable, taking a value of one if other Chinese firms had previously established subsidiaries in the focal Latin American country, and zero otherwise. 
The size of the investment may also matter. Whereas an acquisition provides the acquirer with the managerial and financial resources of the acquired unit, a greenfield investment relies primarily on internal resources (Caves \& Mehra, 1986; Dikova \& Brouthers, 2016). As a result, empirical evidence tend to support that the larger the investment size, the more likely that entry will be through an acquisition (Brouthers \& Brouthers, 2000; Hennart \& Park, 1993; Slangen \& Hennart, 2008). However, an alternative reasoning suggests that, when investment size is large, a greenfield investment may be preferred, since it allows the investor to make an initial smaller investment and increase it gradually later (Brouthers \& Dikova, 2010). Therefore, we included investment size as a control, in millions of US\$ with a $\log$ transformation.

We also controlled for industry effects by including 10 dummy variables, according to the two-digit Global Industry Classification Standard (Meyer et al., 2014). Finally, we included 18-year dummies to capture potentially time-varying influences (Barkema \& Vermeulen, 1998; Bhaumik \& Gelb, 2005; Slangen, 2013; Slangen \& Hennart, 2008).

\section{RESULTS}

Table 2 reports descriptive statistics, bivariate correlations and variance inflation factors (VIFs) between variables. Since all VIFs are well below the recommended cut-off point of 10, this allows us to reject serious multicollinearity problems in our analysis (Kutner et al., 2005).

'Insert Table 2 here'

To test the hypotheses, we used a binomial logistic regression given the dichotomous nature of our dependent variable. The results are displayed in Table 3 with a positive $B$ coefficient meaning a preference for acquisitions and a negative $\beta$ coefficient meaning a preference for greenfield investments.

'Insert Table 3 here' 
Model 1 is the baseline model with only control variables, whereas Model 2 includes the direct effect of the explanatory variable and Model 3 adds the interaction between the explanatory variable and the moderator. All models turned out to be statistically significant ( $\mathrm{p}$ $<0.001$ ). Following the suggestions of Meyer, van Witteloostuijn, and Beugelsdijk (2017), we report odds ratios to assess effect size of each independent variable and the exact p-values to reflect actual statistical significance.

Hypothesis 1 predicted that firm's prior host country experience has a positive effect on the likelihood of choosing acquisitions. This hypothesis is supported, since the regression coefficient of host country experience is positive and significant in Model $2(\beta=0.910, p=$ 0.042). As for the effect size of host country experience, we calculated it as the standard deviation increase times the odds ratio ( $\mathrm{Li}$ et al., 2018). The standard deviation of this variable reported in Table $2(0.42)$ multiplied by its odds ratio in Model 2 as shown in Table $3(2.483)$ gives a result of 1.04. Thus, we can state that a standard deviation increase in firm's prior host country experience makes an acquisition 1.04 times more preferred than a greenfield investment in that host country.

Model 3 tests the moderating effect of government visits. We obtained a statistically significant and negative interaction term $(\beta=-3.430, \mathrm{p}=0.046)$. This result suggests a negative moderating effect of official government visits on the relationship between host country experience and the likelihood that the firm will choose acquisitions. In other words, a recent visit by the Chinese government to a host country reduces the importance of firm's prior host country experience when choosing the establishment mode. Therefore, Hypothesis 2 is also supported.

To help interpret this result, we plotted the relationship between the explanatory and the dependent variables, and the moderating effect of government visits. Based on the results reported in Model 3, Figure 1 illustrates the change on the likelihood of choosing acquisitions 
instead of greenfield investments when the explanatory and the moderating variables change from their low values (one standard deviation below the mean) to their high values (one standard deviation above the mean), keeping all other variables at their mean level. Figure 1 shows that the positive effect of prior host country experience is weaker at high values of government visits than at low values, thus providing further support to Hypothesis 2.

'Insert Figure 1 here'

As for control variables, two of them demonstrated significance in all models, namely, establishment mode experience and investment size. More precisely, we found that Chinese firms with prior experience with an establishment mode tend to use the same mode in subsequent entries, in particular, when that prior experience refers to greenfield subsidiaries. Besides, we obtained that the larger the size of the investment, the more likely that the Chinese MNE will establish through the acquisition of a local company.

\section{Robustness checks}

To assess the sensitive and robustness of our findings, we conducted a number of supplementary analyses. The results are displayed in Table 4.

\section{'Insert Table 4 here'}

First, we replicated the original regressions using the number of subsidiaries established by the firm in the same host country prior to the focal entry as a measure of host country experience. The results of this robustness test, shown in Models 2a and 3a of Table 4, are similar to those reported in our main analysis, although with a lower statistical significance in the case of the interaction term. Second, we ran the regressions using the number of government official visits as an alternative measure for the moderating variable. The results, reported in Models $2 \mathrm{~b}$ and $3 \mathrm{~b}$ of Table 4, are consistent to those obtained in our original regressions, although with a slightly lower statistical significance in both cases. 
Finally, we added several control variables that were not included in our main regression analysis because they were correlated with other variables as indicated by the high VIF values we obtained when conducting multicollinearity tests. Thus, we considered GDP per capita, instead of OECD membership, as a proxy of the level of economic development in the host country. Moreover, we controlled for signs of good diplomatic relations using a dummy variable, coded as one if a comprehensive strategic partnership agreement between China and each host country was in force before the focal investment, and as zero otherwise. In addition, we proxied the intensity of bilateral trade relations by including China's exports to each host country and China's imports from each host country. The results obtained after adding all these control variables, displayed in Models $2 \mathrm{c}$ and $3 \mathrm{c}$ of Table 4, turned out to be similar to those of our original analysis.

\section{DISCUSSION}

This study aimed to advance our understanding of establishment mode decisions made by emerging-market MNEs in other emerging economies. In doing so, we addressed two main questions: (1) to what extent is firm's prior host country experience a factor that facilitates the acquisition of a local target; and (2) are home government official visits to the host country a substitute of host country experience? By integrating insights from information economics and institutional theory, and using China as the home country and Latin America as the host destination, we provided empirical evidence for answering both questions.

With regard to the first question, we obtained that the higher the host country-specific experience by the Chinese investor, the higher the likelihood that it establishes in that country through the acquisition of a local firm instead of by a greenfield subsidiary. Prior research, mainly focused on developed-country MNEs, reported conflicting results regarding the influence of firm's prior host country experience on establishment mode choice. Our findings 
suggest that, when doing business in other emerging economies, emerging-market MNEs may tap their advantage of being familiar with a similar less developed institutional environment like that of their home country. Hence, instead of acquiring a local firm because they lack market knowledge, they opt for acquisitions when they have accumulated host countryspecific experience that allows them to overcome the obstacles derived from the information asymmetries inherent in a cross-border acquisition as well as to increase their local legitimacy.

As for the second question, we obtained that recent official visits paid by the Chinese government to the host country moderate the positive effect of prior entry experience on the choice of acquisitions by Chinese MNEs. Government official visits may replace host country experience as a 'distance-bridging' factor, thus facilitating the entry through the acquisition of a local company. Therefore, for those firms lacking host country-specific experience, the existence of good diplomatic relations between home and host governments may create friendlier local conditions that contribute to reduce the liability of foreignness and to build local legitimacy. In other words, home government support through the development of solid bilateral diplomatic relations may counterbalance the lack of host country experience.

\section{Contributions}

Our study makes several contributions. First, from a theoretical standpoint, we extend both information economics and institutional theory by analyzing how home country institutions, through the establishment of good bilateral diplomatic relationships, may pave the way of host country institutional environment and help to reduce information asymmetries. More precisely, we argue that home government official visits to the host country may act as a substitute of firm's prior experience in that country as a way to alleviate the inspection and interaction problems inherent in cross-border acquisitions, and facilitate local legitimacy building. 
We focused on emerging economies as home and host markets. By using this specific research context, our study contributes to the current epistemological debate on the applicability of extant theories, mainly drawn from developed-country MNEs, for explaining the less conventional behavior of emerging-market MNEs reported by prior studies (Buckley et al., 2018). In doing so, we follow the view by Cuervo-Cazurra (2012) who suggests that, beyond the dichotomy between traditional and new theories, the study of emerging-market MNEs allows to extend theory. Actually, as $\mathrm{Xu}$ and Meyer (2013) suggest, by drawing attention to context-specific characteristics, research on emerging economies is a useful empirical setting for advancing theories.

Second, we also provide new insights on establishment mode decisions by emergingmarket MNEs entering other emerging economies. As pointed out before, past studies addressing the influence of host country-specific experience on establishment mode choice did not focus on emerging economies as home and host counties simultaneously. As for Chinese MNEs, only a few prior studies dealt with establishment mode choice (Anderson \& Sutherland, 2015; Meyer et al., 2014; Quer et al., 2019a; Wu, Liu, \& Huang, 2012). Among them, only that of Quer et al. (2019a) analyzed the influence of host country-specific experience, reporting an insignificant result, although not considering emerging economies as specific destinations.

Our study also offers managerial and policy implications. Emerging economies in general and those of Latin America in particular are becoming increasingly key targets for China's OFDI. Beyond their traditional role as sources of natural resources, now Chinese MNEs look for business opportunities in these countries either as markets or as locations for the development of infrastructure projects. For that reason, the Chinese government is paying special attention on the establishment of friendly diplomatic relations with such emerging economies in order to facilitate operations of Chinese firms. This kind of government support 
is even more relevant in Latin American countries, since cultural distance amplifies the costs of identifying potential local targets and the post-acquisition integration of acquired units. Our results suggest that good bilateral diplomatic relations may be especially useful for those Chinese firms lacking the local knowledge needed for establishing through acquisitions in these destinations.

\section{Limitations}

Our study has a number of limitations. First, the operationalization of variables may constrain the interpretation of our results. In our main analysis, we used dummy variables as a proxy of both the explanatory and the moderator variables. Although when performing the robustness tests we used the number of subsidiaries and the number of government official visits as alternative measures, lack of data prevented us from using other approaches. With regard to the explanatory variable, the length of host country experience in terms of the number of years since the first entry could also matter (Hennart, Sheng, \& Pimenta, 2015). Similarly, as for the moderator, those government official visits with a more specific business orientation might have a strong influence (Voss et al., 2017).

Second, we used secondary data sources in our empirical analysis. This precludes capturing managerial perceptions on to what extent prior host country experience and Chinese government official visits contribute to mitigate inspection and interaction problems associated with acquisitions as well as to increase local legitimacy. Another limitation derives from analyzing establishment mode choice by emerging-market MNEs from a single home country-China-in a single host region-Latin America. The idiosyncratic characteristics of Chinese MNEs as well as those of the relationships between Chinese and Latin American governments may limit the generalization of our findings to other emerging market research settings. 


\section{Future research}

Our study opens avenues for further research. Future studies may use alternative ways for variable operationalization, trying to investigate if the length of firm's host country-specific experience and/or those government official visits including a delegation of Chinese firms' managers have a stronger impact on the reduction of acquisition-related problems. Furthermore, it could be interesting to collect primary data on the perceptions of managers who make decisions on establishment mode. This would allow obtaining information not only on the degree to which firm-specific resources and government support affect, but also on what are the most important perceived barriers when choosing between acquisitions and greenfield investments in a particular host country.

Finally, in order to increase generalizability and transferability of our results, further studies are needed either analyzing establishment mode decisions by Chinese MNEs in other emerging countries outside Latin America, or replicating our study in a broader population of emerging-market MNEs from various home countries entering several emerging economies worldwide. By doing so, future research may contribute to discern whether the abovementioned less conventional behavior of emerging-market MNEs also applies to non-Chinese MNEs or is context-specific.

\section{CONCLUSION}

Our study advances the understanding of the role played by firm-specific factors and bilateral diplomatic relations between countries on establishment mode decisions made by emergingmarket MNEs in other emerging economies. Drawing on information economics and institutional theory, we investigated the interplay between firm's prior host country experience and home government official visits. By examining Chinese MNEs in Latin America, we obtained that, when the foreign firm has prior experience in the host country, an 
acquisition is preferred to a greenfield subsidiary. We argued that prior experience helps the foreign firm to overcome information asymmetries associated with the acquisition of a local firm and to build local legitimacy. Moreover, bilateral diplomatic relations also matter, since our study highlights that recent home government official visits to the focal host country tend to reduce the importance of host country experience.

\section{REFERENCES}

Akerlof, G.A. 1970. The market for "lemons": Quality uncertainty and the market mechanism. The Quarterly Journal of Economics, 84(3): 488-500.

Amighini, A., Rabellotti, R., \& Sanfilipo, M. 2012. Do Chinese SOEs and private companies differ in their foreign location strategies? EUI Working Paper, RSCAS 2012/27, European University Institute, Florence, Italy.

Anderson, J., \& Sutherland, D. 2015. Entry mode and emerging market MNEs: An analysis of Chinese greenfield and acquisition FDI in the United States. Research in International Business and Finance, 35: 88-103.

Andersson, T., \& Svensson, R. 1994. Entry modes for direct investment determined by the composition of firm-specific skills. The Scandinavian Journal of Economics, 96(4): 551-560.

Anwar A., \& Mughal, M. 2013. The role of diaspora in attracting Indian outward FDI. International Journal of Social Economics, 40(11): 944-955.

Barkema, H.G., \& Vermeulen, F. 1998. International expansion through start-up or acquisition: A learning perspective. Academy of Management Journal, 41(1): 7-26.

Bhaumik, S.K., \& Gelb, S. 2005. Determinants of entry mode choice of MNCs in emerging markets: Evidence from South Africa and Egypt. Emerging Markets Finance and Trade, 41(2): 5-24.

Boellis, A., Mariotti, S., Minichilli, A., \& Piscitello, L. 2016. Family involvement and firms' establishment mode choice in foreign markets. Journal of International Business Studies, 47(8): 929-950.

Brouthers, K.D., \& Brouthers, L.E. 2000. Acquisition or greenfield start-up? Institutional, cultural and transaction cost influences. Strategic Management Journal, 21(1): 89-97.

Brouthers, K.D., \& Dikova, D. 2010. Acquisitions and real options: The greenfield alternative. Journal of Management Studies, 47(6): 1048-1071.

Brouthers, K.D., \& Hennart, J.F. 2007. Boundaries of the firm: Insights from international entry mode research. Journal of Management, 33(3): 395-425.

Buckley, P.J., Clegg, L.J., Cross, A.R., Liu, X., Voss, H., \& Zheng, P. 2007. The determinants of Chinese foreign direct investment. Journal of International Business Studies, 38(4): 499-518. 
Buckley, P.J., Clegg, L.J., Voss, H., Cross, A.R., Liu, X., \& Zheng, P. 2018. A retrospective and agenda for future research on Chinese outward foreign direct investment. Journal of International Business Studies, 49(1): 4-23.

Buckley, P.J., Yu, P., Liu, Q., Munjal, S., \& Tao, P. 2016. The institutional influence on the location strategies of multinational enterprises from emerging economies: Evidence from China's crossborder mergers and acquisitions. Management and Organization Review, 12(3): 425-448.

Cantwell, J.A., \& Mudambi, R. 2011. Physical attraction and the geography of knowledge sourcing in multinational enterprises. Global Strategy Journal, 1(3/4): 206-232.

Caves, R.E., \& Mehra, S.K. 1986. Entry of foreign multinationals into U.S. manufacturing industries. In Porter, M.E. (ed.). Competition in Global Industries. Boston, MA. Harvard Business School Press: 449-481.

Chang, S.J., \& Rosenzweig, P.M. 2001. The choice of entry mode in sequential foreign direct investment. Strategic Management Journal, 22(8): 747-776.

Chen, R., Cui, L., Li, S., \& Rolfe, R. 2017. Acquisition or greenfield entry into Africa? Responding to institutional dynamics in an emerging continent. Global Strategy Journal, 7(2): 212-230.

Chen, S.F.S. 2008. The motives for international acquisitions: Capability procurements, strategic considerations, and the role of ownership structures. Journal of International Business Studies, 39(3), 454-471.

Child J., \& Marinova, S. 2014. The role of contextual combinations in the globalization of Chinese firms. Management and Organization Review, 10(3): 347-371.

Child J., Ng, S.H., \& Wong, C. 2002. Psychic distance and internationalization: Evidence from Hong Kong firms. International Studies of Management and Organization, 32(1): 36-56.

Cho, K.R., \& Padmanabhan P. 1995. Acquisition versus new venture: The choice of foreign establishment mode by Japanese firms. Journal of International Management, 1(3): 255-285.

Cohen, W.M., \& Levinthal, D.A. (1990). Absorptive capacity: A new perspective on learning and innovation. Administrative Science Quarterly, 35(1): 128-152.

Cuervo-Cazurra A., \& Genc, M. 2008. Transforming disadvantages into advantages: Developingcountry MNEs in the least developed countries. Journal of International Business Studies, 39(6): 957-979.

Cuervo-Cazurra A., Inkpen, A., Musacchio, A., \& Ramaswamy, K. 2014. Governments as owners: State-owned multinational companies. Journal of International Business Studies, 45(8): 919942.

Cuervo-Cazurra, A. 2012. Extending theory by analyzing developing country multinational companies: Solving the Goldilocks debate. Global Strategy Journal, 2(3): 153-167.

Cui, L., \& Jiang, F. 2010. Behind ownership decision of Chinese outward FDI: Resources and institutions. Asia Pacific Journal of Management, 27(4): 751-774. 
Demirbag, M., Tatoglu, E., \& Glaister, K.W. 2008. Factors affecting perceptions of the choice between acquisition and greenfield entry: The case of Western FDI in an emerging market. Management International Review, 48(1): 5-38.

Deng, P., \& Yang, M. 2015. Cross-border mergers and acquisitions by emerging market firms: A comparative investigation. International Business Review, 24(1): 157-172.

Dikova, D., \& Brouthers, K. 2016. International establishment mode choice: Past, present and future. Management International Review, 56(4): 489-530.

Dikova, D., Sahib, P.R., \& van Witteloostuijn, A. 2010. Cross-border acquisition abandonment and completion: The effect of institutional differences and organizational learning in the international business service industry, 1981-2001. Journal of International Business Studies, 41(2): 223-245.

Dikova D, \& van Witteloostuijn A. 2007. Foreign direct investment mode choice: Entry and establishment modes in transition economies. Journal of International Business Studies, 38(6): 1013-1033.

Dow, D., \& Larimo, J. 2011. Disentangling the roles of international experience and distance in establishment mode choice. Management International Review, 51(3): 321-355.

Drogendijk, R., \& Slangen, A. 2006. Hofstede, Schwartz, or managerial perceptions? The effects of different cultural distance measures on establishment mode choices by multinational enterprises. International Business Review, 15(4): 361-380.

Duanmu, J.L. 2014. State-owned MNCs and host country expropriation risk: The role of home state soft power and economic gunboat diplomacy. Journal of International Business Studies, 45(8): 1044-1060.

Estrin, S., Baghdasaryan, D., \& Meyer, K.E. 2009. The impact of institutional and human resource distance on international entry strategies. Journal of Management Studies, 46(7): 1171-1196.

Fornes, G., \& Butt-Philip, A. 2011. Chinese MNEs and Latin America: A review. International Journal of Emerging Markets, 6(2): 98-117.

Globerman, S., \& Shapiro, D. 2009. Economic and strategic considerations surrounding Chinese FDI in the United States. Asia Pacific Journal of Management, 26(1): 163-183.

Gubbi, S.R., Aulakh, P.S., Ray, S., Sarkar, M.B., \& Chittoor, R. 2010. Do international acquisitions by emerging-economy firms create shareholder value? The case of Indian firms. Journal of International Business Studies, 41(3): 397-418.

Haveman, H.A. 1993. Follow the leader: mimetic isomorphism and entry into new markets. Administrative Science Quarterly 38(4): 593-627.

Hennart, J.F., \& Park, Y.R. 1993. Greenfield vs. acquisition: The strategy of Japanese investors in the United States. Management Science, 39(9): 1054-1070.

Hennart, J.F., Sheng, H.H., \& Pimenta, G. 2015. Local complementary inputs as drivers of entry mode choices: The case of US investments in Brazil. International Business Review, 24(3): 466-475. 
Hofstede, G., Hofstede, G.J., \& Minkov, M. 2010. Cultures and Organizations. Software of the Mind. Intercultural Cooperation and its Importance for Survival. $3^{\text {rd }}$ edition. New York: McGrawHill.

Jiang, G.F., Holburn, G.L.F., \& Beamish, P.W. 2014. The impact of vicarious experience on foreign location strategy. Journal of International Management, 20(3): 345-358.

Kaufmann, D., Kraay, D., \& Mastruzzi, M. 2009. Governance matters VIII: Aggregate and individual governance indicators 1996-2008. Policy Research Working Paper 4978, The World Bank, Washington DC.

Klier, H., Schwens, C., Zapkau, F.B., \& Dikova, D. 2017. Which resources matter how and where? A Meta-analysis on firms' establishment mode choice. Journal of Management Studies, 54(3): 304-339.

Kogut, B., \& Singh, H. 1988. The effect of national culture on the choice of entry mode. Journal of International Business Studies, 19(3): 411-432.

Kostova, T., Roth, K., \& Dacin, M.T. 2008. Institutional theory in the study of multinational corporations: A critique and new directions. Academy of Management Review, 33(4): 994 1006.

Kostova, T., \& Zaheer, S. 1999. Organizational legitimacy under conditions of complexity: The case of the multinational enterprise. Academy of Management Review, 24(1): 64-81.

Kutner, M.H., Nachtsheim, C.J., Neter, J., \& Li, W. 2005. Applied Linear Statistical Models. $5^{\text {th }}$ edition. New York: McGraw-Hill/Irwin.

Larimo, J. 2003. Form of investment by Nordic firms in world markets. Journal of Business Research, 56(10): 791-803.

Lattemann, C., Alon, I., Spigarelli, F., \& Marinova, S. 2017. Dynamic embeddedness in Chinese firm internationalization. Thunderbird International Business Review, 59(4): 547-559.

Li. J., Li, Y., \& Shapiro, D. 2012. Knowledge seeking and outward FDI of emerging market firms: The moderating effect of inward FDI. Global Strategy Journal, 2(4): 277-295.

Li, J., Meyer, K.E., Zhang, H., \& Ding, Y. 2018. Diplomatic and corporate networks: Bridges to foreign locations. Journal of International Business Studies, 49(6): 659-693.

Liu, X., Gao, L., Lu, J., \& Lioliou, E. 2016. Does learning at home and from abroad boost the foreign subsidiary performance of emerging economy multinational enterprises? International Business Review, 25(1): 141-151.

Lu, J., Liu, X., Wright, M., \& Filatotchev, I. 2014. International experience and FDI location choices of Chinese firms: The moderating effects of home country government support and host country institutions. Journal of International Business Studies, 45(4): 428-449.

Luo, Y., \& Tung, R.L. 2007. International expansion of emerging-market enterprises: A springboard perspective. Journal of International Business Studies, 38(4): 481-498. 
Luo, Y., Xue, Q., \& Han, B. 2010. How emerging market governments promote outward FDI: Experience from China. Journal of World Business, 45(1): 68-79.

Meyer, K.E., Ding, Y., Li, J., \& Zhang, H. 2014. Overcoming distrust: How state-owned enterprises adapt their foreign entries to institutional pressures abroad. Journal of International Business Studies, 45(8): 1005-1028.

Meyer, K.E., Estrin, S., Bhaumik, S.K., \& Peng, M.W. 2009. Institutions, resources, and entry strategies in emerging economies. Strategic Management Journal, 30(1): 61-80.

Meyer, K.E., van Witteloostuijn, A., \& Beugelsdijk, S. 2017. What's in a p? Reassessing best practices for conducting and reporting hypothesis testing research. Journal of International Business Studies, 48(5): 535-551.

Mudambi, R., \& Mudambi, S.M. 2002. Diversification and market entry choices in the context of foreign direct investment. International Business Review, 11(1): 35-55.

Nagano, M. 2013. Similarities and differences among cross-border MandA and greenfield FDI determinants: Evidence from Asia and Oceania. Emerging Markets Review, 16: 100-118.

NBS. 2018. National data. Overseas direct investment by countries or regions. National Bureau of Statistics of China: Beijing. Available at: http://data.stats.gov.cn/english/ (accessed 24 July 2018).

Nitsch, V. 2007. State visits and international trade. The World Economy, 30(12): 1797-1816.

North, D.C. 1990. Institutions, Institutional Change and Economic Performance. Cambridge, UK: Cambridge University Press.

Padmanabhan, P., \& Cho, K.R. 1999. Decision specific experience in foreign ownership and establishment strategies: Evidence from Japanese firms. Journal of International Business Studies, 30(1): 25-44.

Pedersen, T., \& Shaver, M. 2011. Internationalization revisited: The big step hypothesis. Global Strategy Journal, 1(3/4): 263-274.

Peng, M.W., Wang, D.Y.L., \& Jiang, Y. 2008. An institution-based view of international business strategy: A focus on emerging economies. Journal of International Business Studies, 39(5): 920-936.

Quer, D., Rienda, L., \& Andreu, R. 2019a. Foreign direct investment drivers and establishment mode choice of emerging-market MNEs: The role of state ownership. European Journal of International Management, forthcoming.

Quer, D., Rienda, L., Andreu, R., \& Miao, S. (2019b): Host country experience, institutional distance and location choice of Chinese MNEs: The moderating effect of government official visits. Cross Cultural \& Strategic Management, 26(1): 24-45.

Ravenscraft, D.J., \& Scherer, F.M. 1987. Mergers, Sell-Offs, and Economic Efficiency. Washington, DC: Brookings Institution Press. 
Rienda, L., Claver, E., \& Quer, D. 2013. The internationalisation of Indian multinationals: Determinants of expansion through acquisitions. Journal of the Asia Pacific Economy, 18(1): $115-132$.

Schwens, C., Zapkau, F.B., Brouthers, K.D., \& Hollender, L. 2018. Limits to international entry mode learning in SMEs. Journal of International Business Studies, 49(7): 809-831.

Shapiro, D.M., Vecino C., \& Li, J. 2018. Exploring China's state-led FDI model: Evidence from the extractive sectors in Latin America. Asia Pacific Journal of Management, 35(1): 11-37.

Shaver, J.M. 1998. Accounting for endogeneity when assessing strategy performance: Does entry mode choice affect FDI survival? Management Science, 44(4): 571-585.

Slangen, A.H.L., \& Hennart, J.F. 2007. Greenfield or acquisition entry: A review of the empirical foreign establishment mode literature. Journal of International Management, 13(4): 403-429.

Slangen, A.H.L., \& Hennart, J.F. 2008. Do multinationals really prefer to enter culturally distant countries through greenfields rather than through acquisitions? The role of parent experience and subsidiary autonomy. Journal of International Business Studies, 39(3): 472-490.

Slangen, A.H.L. 2011. A communication-based theory of the choice between greenfield and acquisition entry. Journal of Management Studies, 48(8): 1699-1726.

Slangen, A.H.L. 2013. Greenfield or acquisition entry? The roles of policy uncertainty and MNE legitimacy in host countries. Global Strategy Journal, 3(3): 262-280.

Stigler, G.J. 1961. The economics of information. The Journal of Political Economy, 69(3): 213-225.

Tan, D., \& Meyer, K.E. 2011. Country-of-origin and industry FDI agglomeration of foreign investors in an emerging economy. Journal of International Business Studies, 42(4): 504-520.

UNCTAD. 2018. World Investment Report 2018. Investment and New Industrial Policies. New York and Geneva: United Nations Conference on Trade and Development.

Voss, H., Buckley, P.J., Chen, L., \& Clegg, J. 2017. The role of experience in FDI location choice: Endogenous risk, exogenous risk, and high-level government visits. Paper presented at the 11th Annual China goes Global Conference, Kristiansand, Norway.

Wright, M., Filatotchev, I., Hoskisson, R.E., \& Peng, M.W. 2005. Strategy research in emerging economies: Challenging the conventional wisdom. Journal of Management Studies, 42(1): 133.

Wu, X., Liu, X., \& Huang, Q. 2012. Impact of the institutional environment on the choice of entry mode: Evidence from Chinese enterprises. China: An International Journal, 10(1): 28-50.

Xie, E., Reddy, K.S., \& Liang, J. 2017. Country-specific determinants of cross-border mergers and acquisitions: A comprehensive review and future research directions. Journal of World Business, 52(2):127-183.

Xu, D., \& Meyer, K.E. 2013. Linking theory and context: 'Strategy research in emerging economies' after Wright et al. 2005. Journal of Management Studies, 50(7): 1322-1346. 
Xu, D., \& Shenkar, O. 2002. Institutional distance and the multinational enterprise. Academy of Management Review, 27(4): 608-618.

Xu, G., Guo, B., Li, W., \& Wang, X. 2018. Foreign sequential entry mode choice: A structural inertia perspective and evidence from Chinese firms. Baltic Journal of Management, 13(4): 544-563.

Yuan, L., \& Pangarkar, N. 2010. Inertia versus mimicry in location choices by Chinese multinationals. International Marketing Review, 27(3): 295-315.

Zaheer, S., \& Mosakowski, E. 1997. The dynamics of the liability of foreignness: A global study of survival in financial services. Strategic Management Journal, 18(6): 439-464.

Zhang, J., Jiang, J., \& Zhou, C. 2014. Diplomacy and investment - the case of China. International Journal of Emerging Markets, 9(2): 216-235. 
Table 1. Sample description

\begin{tabular}{|c|c|c|}
\hline & Observations & Percent \\
\hline \multicolumn{3}{|l|}{ Establishment mode } \\
\hline Greenfield investment & 209 & 66.3 \\
\hline Acquisition & 106 & 33.7 \\
\hline \multicolumn{3}{|l|}{ Host country } \\
\hline Brazil & 134 & 42.5 \\
\hline Mexico & 49 & 15.6 \\
\hline Peru & 29 & 9.2 \\
\hline Argentina & 25 & 7.9 \\
\hline Venezuela & 18 & 5.7 \\
\hline Chile & 17 & 5.4 \\
\hline Ecuador & 15 & 4.8 \\
\hline Colombia & 9 & 2.9 \\
\hline Panama & 8 & 2.5 \\
\hline Bolivia & 4 & 1.3 \\
\hline Cuba & 2 & 0.6 \\
\hline Uruguay & 2 & 0.6 \\
\hline El Salvador & 1 & 0.3 \\
\hline Honduras & 1 & 0.3 \\
\hline Nicaragua & 1 & 0.3 \\
\hline \multicolumn{3}{|l|}{ Industry } \\
\hline Materials & 53 & 16.8 \\
\hline Telecommunication services & 52 & 16.5 \\
\hline Energy & 50 & 15.9 \\
\hline Industrials & 45 & 14.3 \\
\hline Consumer discretionary & 44 & 14 \\
\hline Financials & 31 & 9.8 \\
\hline Consumer staples & 21 & 6.7 \\
\hline Utilities & 9 & 2.9 \\
\hline Information technology & 8 & 2.5 \\
\hline Health care & 2 & 0.6 \\
\hline \multicolumn{3}{|l|}{ Investor } \\
\hline Huawei & 15 & 4.8 \\
\hline China National Petroleum Corporation [CNPC] & 12 & 3.8 \\
\hline China Three Gorges & 8 & 2.5 \\
\hline Sinopec & 7 & 2.2 \\
\hline State Grid & 7 & 2.2 \\
\hline Aluminum Corporation of China [Chinalco] & 6 & 1.9 \\
\hline China Construction Bank & 5 & 1.6 \\
\hline China Fishery Group & 5 & 1.6 \\
\hline China Minmetals & 5 & 1.6 \\
\hline Industrial and Commercial Bank of China [ICBC] & 5 & 1.6 \\
\hline Sany Heavy Industry Co. & 5 & 1.6 \\
\hline ZTE & 5 & 1.6 \\
\hline Other & 230 & 73 \\
\hline Total sample & 315 & 100 \\
\hline
\end{tabular}


Table 2. Descriptive statistics and correlations

\begin{tabular}{|c|c|c|c|c|c|c|c|c|c|c|c|c|c|c|c|c|c|c|c|c|}
\hline & Variables & Mean & SD & VIF & 1 & 2 & 3 & 4 & 5 & 6 & 7 & 8 & 9 & 10 & 11 & 12 & 13 & 14 & 15 & 16 \\
\hline 1 & Establishment mode & 0.34 & 0.47 & N.A. & 1 & & & & & & & & & & & & & & & \\
\hline 2 & $\begin{array}{l}\text { Host country } \\
\text { experience }\end{array}$ & 0.23 & 0.42 & 1.61 & 0.214 & 1 & & & & & & & & & & & & & & \\
\hline 3 & Government visit & 0.91 & 0.29 & 1.94 & 0.081 & 0.039 & 1 & & & & & & & & & & & & & \\
\hline 4 & Cultural distance & 2.73 & 0.84 & 4.42 & -0.216 & -0.149 & -0.246 & 1 & & & & & & & & & & & & \\
\hline 5 & Diaspora & 0.45 & 0.80 & 2.10 & 0.092 & 0.101 & 0.052 & 0.150 & 1 & & & & & & & & & & & \\
\hline 6 & $\begin{array}{l}\text { Government } \\
\text { effectiveness }\end{array}$ & -0.13 & 0.43 & 3.51 & -0.044 & -0.107 & 0.033 & 0.038 & -0.408 & 1 & & & & & & & & & & \\
\hline 7 & $\begin{array}{l}\text { Resource } \\
\text { endowment }\end{array}$ & 1.36 & 0.47 & 1.97 & 0.015 & 0.043 & 0.409 & -0.115 & 0.336 & -0.275 & 1 & & & & & & & & & \\
\hline 8 & $\begin{array}{l}\text { Technology } \\
\text { endowment }\end{array}$ & -7.94 & 0.20 & 3.24 & 0.067 & -0.057 & 0.003 & -0.368 & -0.386 & 0.329 & -0.033 & 1 & & & & & & & & \\
\hline 9 & Market growth & 2.59 & 3.79 & 3.15 & -0.112 & -0.126 & -0.078 & 0.125 & 0.244 & 0.064 & 0.076 & -0.110 & 1 & & & & & & & \\
\hline 10 & $\begin{array}{l}\text { Economic } \\
\text { development }\end{array}$ & 0.21 & 0.41 & 5.66 & -0.169 & -0.116 & 0.051 & 0.500 & -0.226 & 0.643 & -0.035 & 0.225 & 0.051 & 1 & & & & & & \\
\hline 11 & Firm size & 4.40 & 0.96 & 2.14 & -0.028 & 0.213 & -0.042 & 0.010 & 0.041 & -0.173 & 0.092 & -0.127 & -0.059 & -0.124 & 1 & & & & & \\
\hline 12 & State ownership & 39.12 & 41.79 & 2.22 & 0.178 & 0.151 & 0.058 & -0.092 & 0.070 & -0.161 & 0.148 & -0.016 & -0.078 & -0.153 & 0.466 & 1 & & & & \\
\hline 13 & $\begin{array}{l}\text { Acquisition } \\
\text { experience }\end{array}$ & 0.25 & 0.40 & 2.62 & 0.321 & 0.416 & 0.107 & -0.158 & 0.114 & -0.156 & 0.101 & -0.124 & -0.234 & -0.203 & 0.283 & 0.475 & 1 & & & \\
\hline 14 & $\begin{array}{l}\text { Greenfield } \\
\text { experience }\end{array}$ & 0.21 & 0.31 & 2.25 & 0.009 & 0.380 & 0.055 & 0.063 & 0.194 & -0.173 & 0.059 & -0.269 & -0.027 & -0.150 & 0.454 & 0.308 & 0.466 & 1 & & \\
\hline 15 & Vicarious experience & 0.94 & 0.24 & 2.86 & 0.011 & 0.139 & 0.343 & -0.113 & -0.025 & 0.085 & 0.032 & -0.107 & -0.118 & 0.065 & -0.043 & -0.019 & 0.147 & 0.110 & 1 & \\
\hline 16 & Investment size & 1.88 & 0.97 & 2.06 & 0.335 & 0.255 & 0.034 & -0.192 & 0.133 & -0.119 & 0.006 & -0.051 & -0.092 & -0.239 & 0.299 & 0.422 & 0.415 & 0.279 & 0.117 & 1 \\
\hline
\end{tabular}

Notes: No. of observations $=315$. Correlations with absolute values above 0.112 are significant at $5 \%$. 
Table 3. Binomial logistic regression results of establishment mode choice

\begin{tabular}{|c|c|c|c|c|c|c|c|c|c|c|c|c|}
\hline & \multicolumn{4}{|c|}{ Model 1} & \multicolumn{4}{|c|}{ Model 2} & \multicolumn{4}{|c|}{ Model 3} \\
\hline & B & SE & OR & p-value & ß & SE & OR & $\mathrm{p}$-value & B & SE & OR & $\mathrm{p}$-value \\
\hline \multicolumn{13}{|l|}{ Explanatory variable } \\
\hline Host country experience & & & & & 0.910 & 0.447 & 2.483 & 0.042 & 4.193 & 1.720 & 66.206 & 0.015 \\
\hline \multicolumn{13}{|l|}{ Moderating variable } \\
\hline Government visit & & & & & 1.463 & 0.814 & 4.320 & 0.072 & 2.479 & 1.024 & 11.933 & 0.016 \\
\hline \multicolumn{13}{|l|}{ Interaction } \\
\hline $\begin{array}{l}\text { Host country experience } \mathrm{x} \\
\text { Government visit }\end{array}$ & & & & & & & & & -3.430 & 1.723 & 0.032 & 0.046 \\
\hline \multicolumn{13}{|l|}{ Control variables } \\
\hline Cultural distance & -0.353 & 0.375 & 0.702 & 0.346 & -0.015 & 0.406 & 0.985 & 0.971 & 0.031 & 0.415 & 1.032 & 0.940 \\
\hline Diaspora & 0.118 & 0.254 & 1,126 & 0.641 & 0.071 & 0.261 & 1.074 & 0.784 & 0.128 & 0.269 & 1.137 & 0.633 \\
\hline Government effectiveness & -0.061 & 0.679 & 0.941 & 0.929 & 0.156 & 0.692 & 1.169 & 0.821 & 0.241 & 0.706 & 1.273 & 0.733 \\
\hline Resource endowment & -0.036 & 0.460 & 0.965 & 0.938 & -0.270 & 0.498 & 0.763 & 0.587 & -0.462 & 0.519 & 0.630 & 0.373 \\
\hline Technology endowment & 1.063 & 1.444 & 2.896 & 0.462 & 1.516 & 1.546 & 4.555 & 0.327 & 2.165 & 1.640 & 8.717 & 0.187 \\
\hline Market growth & 0.053 & 0.077 & 1.054 & 0.492 & 0.076 & 0.080 & 1.079 & 0.344 & 0.105 & 0.085 & 1,110 & 0.216 \\
\hline Economic development & -0.325 & 0.964 & 0.722 & 0.736 & -0.962 & 0.987 & 0.382 & 0.330 & -1.070 & 0.996 & 0.343 & 0.283 \\
\hline Firm size & -0.242 & 0.254 & 0.785 & 0.341 & -0.212 & 0.262 & 0.809 & 0.418 & -0.234 & 0.266 & 0.791 & 0.379 \\
\hline State ownership & 0.003 & 0.006 & 1.003 & 0.568 & 0.004 & 0.006 & 1.004 & 0.458 & 0.005 & 0.006 & 1.005 & 0.416 \\
\hline Acquisition experience & 1.221 & 0.622 & 3.392 & 0.049 & 1.017 & 0.641 & 2.764 & 0.113 & 1.122 & 0.657 & 3.070 & 0.088 \\
\hline Greenfield experience & -1.659 & 0.797 & 0.190 & 0.037 & -2.212 & 0.858 & 0.109 & 0.010 & -2.331 & 0.848 & 0.097 & 0.006 \\
\hline Vicarious experience & -1.304 & 1.104 & 0.271 & 0.238 & -1.513 & 1.100 & 0.220 & 0.169 & -1.943 & 1.134 & 0.143 & 0.087 \\
\hline Investment size & 0.633 & 0.237 & 1.883 & 0.008 & 0.597 & 0.239 & 1.817 & 0.012 & 0.620 & 0.241 & 1.858 & 0.010 \\
\hline \multicolumn{13}{|l|}{ Fit measures } \\
\hline Chi-square & \multicolumn{4}{|c|}{$122.199(\mathrm{p}$-value $=0.000)$} & \multicolumn{4}{|c|}{$129.198(\mathrm{p}$-value $=0.000)$} & \multicolumn{4}{|c|}{$132.975(\mathrm{p}$-value $=0.000)$} \\
\hline Overall \% correct & \multicolumn{4}{|c|}{82.4} & \multicolumn{4}{|c|}{82.4} & \multicolumn{4}{|c|}{82.4} \\
\hline$-2 \log$ likelihood & \multicolumn{4}{|c|}{256.933} & \multicolumn{4}{|c|}{249.934} & \multicolumn{4}{|c|}{246.157} \\
\hline Nagelkerke R Square & \multicolumn{4}{|c|}{0.469} & \multicolumn{4}{|c|}{0.490} & \multicolumn{4}{|c|}{0.502} \\
\hline
\end{tabular}

Notes: No. of observations $=315$. Dependent variable: (1) acquisition; (0) greenfield investment.

$S E$ Standard error, OR Odds ratio. Industry and year dummies are included but not shown. 
Table 4. Binomial logistic regression results of establishment mode choice (Robustness checks)

\begin{tabular}{|c|c|c|c|c|c|c|c|c|c|c|c|c|}
\hline & \multicolumn{2}{|c|}{ Model 2a } & \multicolumn{2}{|c|}{ Model 3a } & \multicolumn{2}{|c|}{ Model 2b } & \multicolumn{2}{|c|}{ Model 3b } & \multicolumn{2}{|c|}{ Model 2c } & \multicolumn{2}{|c|}{ Model 3c } \\
\hline & B & $\mathrm{p}$-value & $\beta$ & $\mathrm{p}$-value & B & $\mathrm{p}$-value & ß & $\mathrm{p}$-value & B & $\mathrm{p}$-value & B & p-value \\
\hline \multicolumn{13}{|l|}{ Explanatory variable } \\
\hline Host country experience & 2.339 & 0.037 & 9.830 & 0.036 & 0.831 & 0.062 & 2.535 & 0.016 & 0.904 & 0.047 & 4.287 & 0.012 \\
\hline \multicolumn{13}{|l|}{ Moderating variable } \\
\hline Government visit & 1.456 & 0.075 & 2.225 & 0.025 & 0.631 & 0.055 & 0.954 & 0.012 & 1.885 & 0.048 & 3.031 & 0.010 \\
\hline \multicolumn{13}{|l|}{ Interaction } \\
\hline $\begin{array}{l}\text { Host country experience x Government } \\
\text { visit }\end{array}$ & & & -7.752 & 0.100 & & & -1.232 & 0.072 & & & -3.565 & 0.038 \\
\hline \multicolumn{13}{|l|}{ Control variables } \\
\hline Cultural distance & -0.013 & 0.974 & 0.024 & 0.953 & -0.160 & 0.682 & -0.096 & 0.810 & -0.656 & 0.164 & -0.723 & 0.140 \\
\hline Diaspora & 0.085 & 0.743 & 0.129 & 0.628 & 0.099 & 0.702 & 0.127 & 0.624 & 0.164 & 0.650 & 0.194 & 0.614 \\
\hline Government effectiveness & 0.164 & 0.813 & 0.240 & 0.733 & 0.106 & 0.878 & 0.117 & 0.868 & -0.256 & 0.659 & -0.158 & 0.799 \\
\hline Resource endowment & -0.276 & 0.580 & -0.436 & 0.401 & -0.219 & 0.651 & -0.355 & 0.479 & -0.432 & 0.465 & -0.652 & 0.296 \\
\hline Technology endowment & 1.462 & 0.344 & 1.880 & 0.242 & 1.258 & 0.402 & 1.920 & 0.226 & 1.871 & 0.354 & 2.390 & 0.276 \\
\hline Market growth & 0.075 & 0.348 & 0.097 & 0.245 & 0.083 & 0.306 & 0.095 & 0.245 & 0.051 & 0.566 & 0.073 & 0.436 \\
\hline Economic development & -0.946 & 0.337 & -1.025 & 0.301 & -0.858 & 0.385 & -0.984 & 0.328 & 1.608 & 0.578 & 1.370 & 0.653 \\
\hline Firm size & -0.199 & 0.449 & -0.233 & 0.379 & -0.186 & 0.479 & -0.168 & 0.528 & -0.222 & 0.405 & -0.244 & 0.367 \\
\hline State ownership & 0.004 & 0.488 & 0.004 & 0.457 & 0.004 & 0.459 & 0.005 & 0.348 & 0.004 & 0.466 & 0.005 & 0.438 \\
\hline Acquisition experience & 0.983 & 0.125 & 1.035 & 0.111 & 1.005 & 0.117 & 1.068 & 0.105 & 1.110 & 0.090 & 1.230 & 0.067 \\
\hline Greenfield experience & -2.331 & 0.008 & -2.314 & 0.007 & -2.191 & 0.011 & -2.287 & 0.008 & -2.303 & 0.011 & -2.391 & 0.007 \\
\hline Vicarious experience & -1.485 & 0.178 & -1.760 & 0.115 & -1.328 & 0.226 & -1.438 & 0.189 & -1.362 & 0.233 & -1.734 & 0.137 \\
\hline Investment size & 0.610 & 0.011 & 0.639 & 0.008 & 0.617 & 0.010 & 0.618 & 0.010 & 0.633 & 0.010 & 0.668 & 0.007 \\
\hline Strategic partnership & & & & & & & & & 0.107 & 0.902 & 0.316 & 0.725 \\
\hline China's exports & & & & & & & & & -0.737 & 0.403 & -0.791 & 0.379 \\
\hline China's imports & & & & & & & & & -0.562 & 0.599 & -0.724 & 0.528 \\
\hline \multicolumn{13}{|l|}{ Fit measures } \\
\hline Chi-square & $\begin{array}{r}129 \\
\text { (p-value }\end{array}$ & $\begin{array}{l}523 \\
=0.000)\end{array}$ & $\begin{array}{r}13 \\
(\mathrm{p}-\mathrm{valu}\end{array}$ & $\begin{array}{l}134 \\
=0.000)\end{array}$ & $\begin{array}{r}129 \\
\text { (p-value }\end{array}$ & $\begin{array}{l}387 \\
=0.000)\end{array}$ & $\begin{array}{r}132 \\
\text { (p-value }\end{array}$ & $\begin{array}{l}615 \\
=0.000)\end{array}$ & $\begin{array}{r}13 \\
(\mathrm{p}-\mathrm{valu}\end{array}$ & $\begin{array}{l}072 \\
=0.000)\end{array}$ & $\begin{array}{r}13 \\
\text { (p-valu }\end{array}$ & $\begin{array}{l}260 \\
=0.000)\end{array}$ \\
\hline Overall \% correct & & & & & & & & & & & & \\
\hline$-2 \log$ likelihood & 249 & 609 & & 999 & 249 & 745 & $24 c$ & 517 & & 060 & & 872 \\
\hline Nagelkerke R Square & 0. & & & & & & & & & & & 05 \\
\hline
\end{tabular}

Notes: No. of observations $=315$. Dependent variable: (1) acquisition; (0) greenfield investment.

Industry and year dummies are included but not shown. Standard errors and Odds ratios are not reported but are available upon request. 


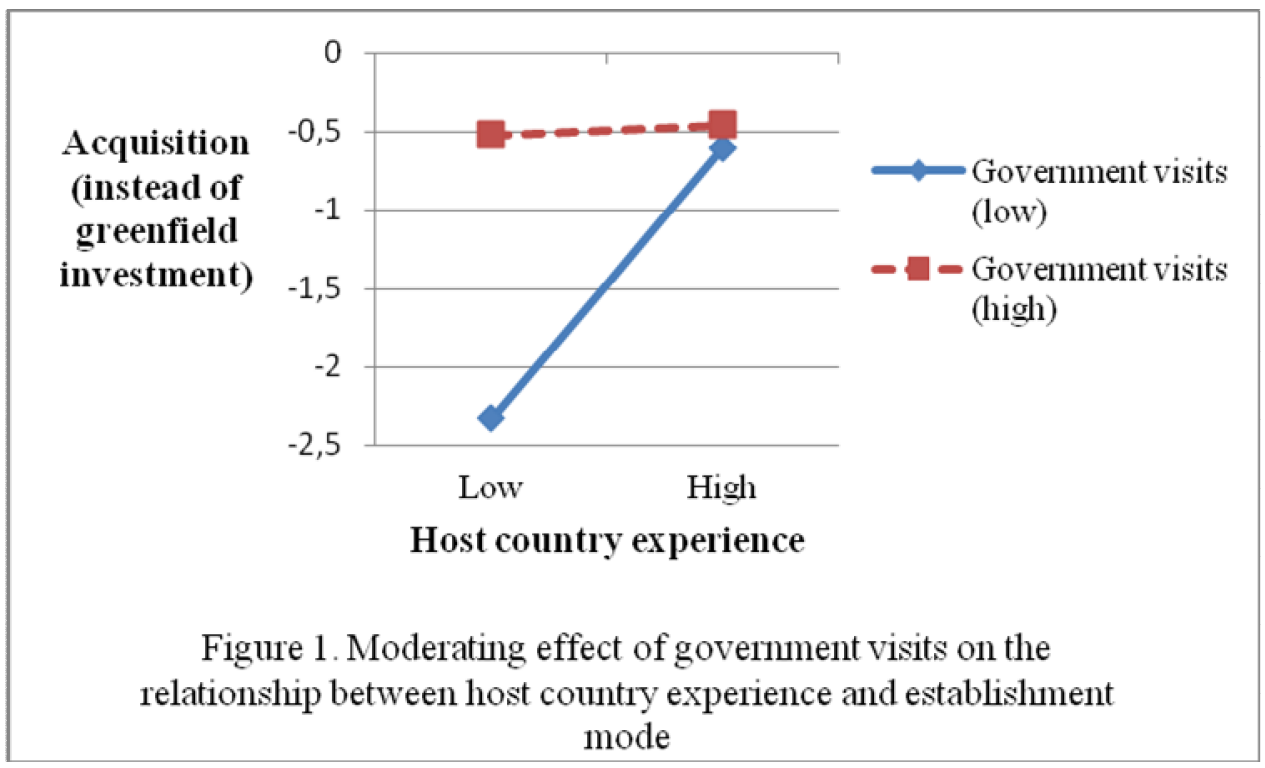

